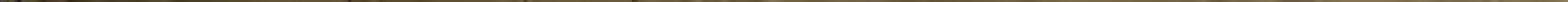



Please do not destroy or throw away this publication. If you have no further use for it, write to the Geological Survey at Washington and ask for a frank to return it

DEPARTMENT OF THE INTERIOR

HuBERT Work, Secretary

UNITED STATES GEOLOGICAL SURVEY

George Otis SMith, Director

Professional Paper 132-C

\title{
NOTES ON THE GEOLOGY OF GREEN RIVER VALLEY BETWEEN GREEN RIVER, WYOMING, AND GREEN RIVER, UTAH
}

\author{
BY \\ JOHN B. REESIDE, Jr. \\ Published November 30, 1923 \\ Shorter contributions to general geology, 1923 \\ (Pageg 35-50)

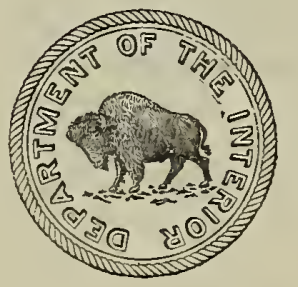 \\ WASHINGTON \\ GOVERNMEN'T PRINTING OFFICE \\ 1923
}




\section{CONTENTS.}

Introduction

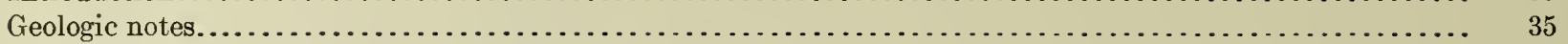

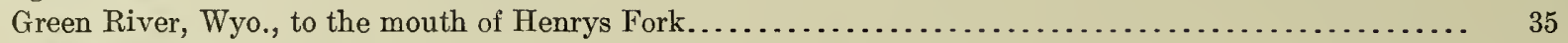

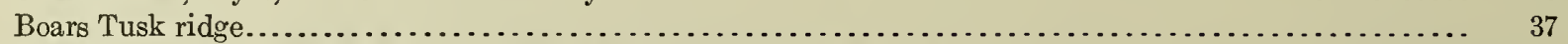

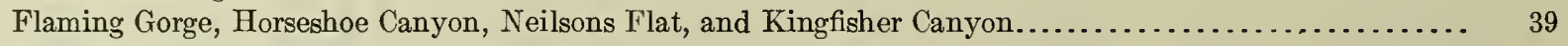

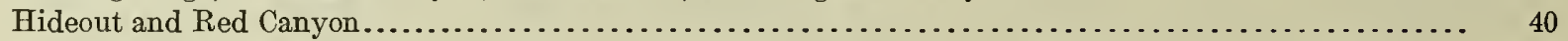

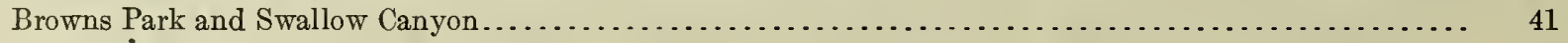

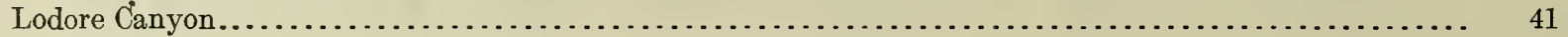

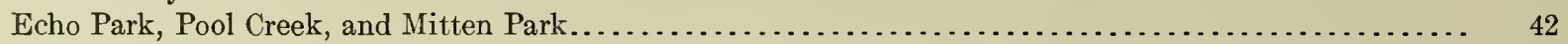

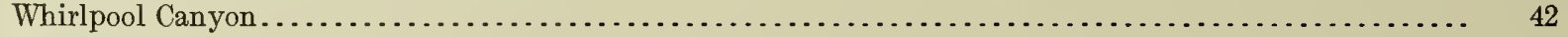

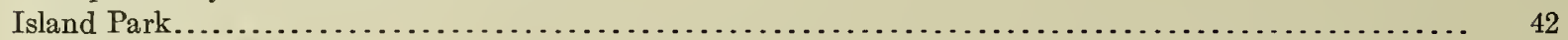

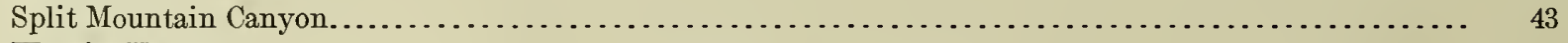

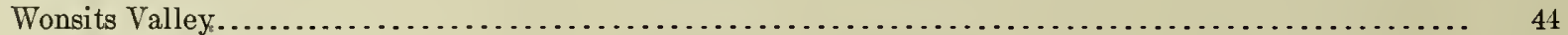

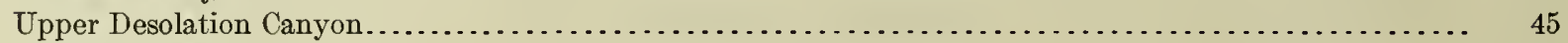

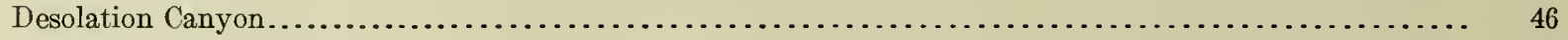

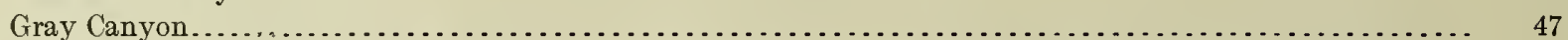

Comparison of the lithologic succession in Green River valley, southwestern Utah, and central Wyoming..... 47

\section{ILLUSTRATIONS.}

FIGURE 2. Sketch map of Green River between Green River, Wyo, and Green River, Utah...............

3. Map showing Green River between the mouth of Henrys Fork and the mouth of Skull Canyon,

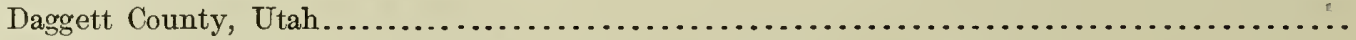

4. Section of the north slope of the Boars Tusk ridge, Daggett County, Utah ....................

5. Cross section of the ridge east of the Boars Tusk ridge, Daggett County, Utah.................

6. Diagrammatic sketch of the bluff northwest of Neilsons Flat, Daggett County, Utah..............

7. Diagram showing correlation of sections near Flaming Gorge, Daggett County, and in Island Park and near the Carnegie Museum dinosaur quarry, Uinta County, Utah. 


\title{
NOTES ON THE GEOLOGY OF GREEN RIVER VALLEY BETWEEN GREEN RIVER, WYOMING, AND GREEN RIVER, UTAH.
}

\author{
By JoHn B. Reeside, Jr.
}

\section{INTRODUCTION.}

During July, August, and part of September, 1922, I had the privilege of accompanying a party sent out jointly by the Utah Power \& Light Co. and the United States Geological Survey to gather such data as were still needed to complete a study of the power resources of Green River between Green River, Wyo., and Green River, Utah. The chief deficiency to be supplied was a continuous topographic map of the valley in sufficient detail to permit calculation of the storage capacity of any reservoir site that might be used, the stream gradient, and similar features. Maps on a satisfactory scale of a number of isolated stretches of the river had already been made by public or private agencies, and it was necessary to verify them and connect them on a uniform datum. Inasmuch as it was deemed unlikely that a dam higher than 300 feet would be constructed anywhere on the part of the river to be examined, a plane 300 feet above the water surface was made the upper limit of mapping. Over such parts of the valley as had been mapped already the progress of the party was naturally very rapid, and even where no mapping had previously been done, the 300 -foot limit set upon the work and the usual narrowness of the valley combined to reduce the extent of the area to be mapped, so that the speed maintained was relatively high. Under this condition of rapid movement it was seldom possible to make more than the most cursory examination of the rocks, though occasionally circumstances permitted more or less detailed observation. The notes here recorded are therefore mostly of a rather generalized character, but as they pertain in part to localities that are difficult of access and not often visited by geologists, and that are at the same time classic in the history of American geology, I venture to to record them for whatever value they may have to other geologists.

\section{GEOLOGIC NOTES.}

Green River, Wyo., to the mouth of Henrys Fork.-Most of the part of Green River valley lying between Green River, Wyo., and Henrys Fork is cut in rocks assigned to the Green River formation (lower Eocene). This formation includes a lower division of whitish, gray, and greenish fissile shale, light-colored limestone, and sandstone and an upper division of massive, irregularly bedded brown sandstone with some sandy limestone and shale-the "Tower sandstone" and "plant beds" of Powell. ${ }^{1}$ Over much of the way the "Tower sandstone" caps the bluffs along the river, and the gray mass of shaly beds beneath it forms steep slopes. The dips of the beds are low, usually so low that they are not apparent to the eye.

As the mouth of Henrys Fork is approached the influence of the Uinta uplift shows in the appearance of an appreciable northward dip. About 6 miles above the mouth of Henrys Fork this dip increases very much, and the river, running nearly across the strike of the beds, quickly passes out of the Green River formation into the beds mapped by Schultz ${ }^{2}$ as Wasatch formation (lower Eocene). These beds consist of white to brown sandstone, gray shale, and red shale and are said to contain some coal.

From the Wasatch exposures the river passes through beds that dip $40^{\circ}-50^{\circ} \mathrm{N}$. and have been assigned by Schultz ${ }^{2}$ to the Lewis

1 Powell, J. W., Report on the geology of the eastern portion of the Uinta Mountains, pp. 40, 45, U. S. Geol. and Geog. Survey Terr., 1876. 2 Sehultz, A. R., Oil possibilities in and around Baxter Basin, in the Rock Springs uplift, Sweetwater County, Wyo.: U. S. Geol. Survey Bull. 702, pl. 1, fig. 3, 1920. 


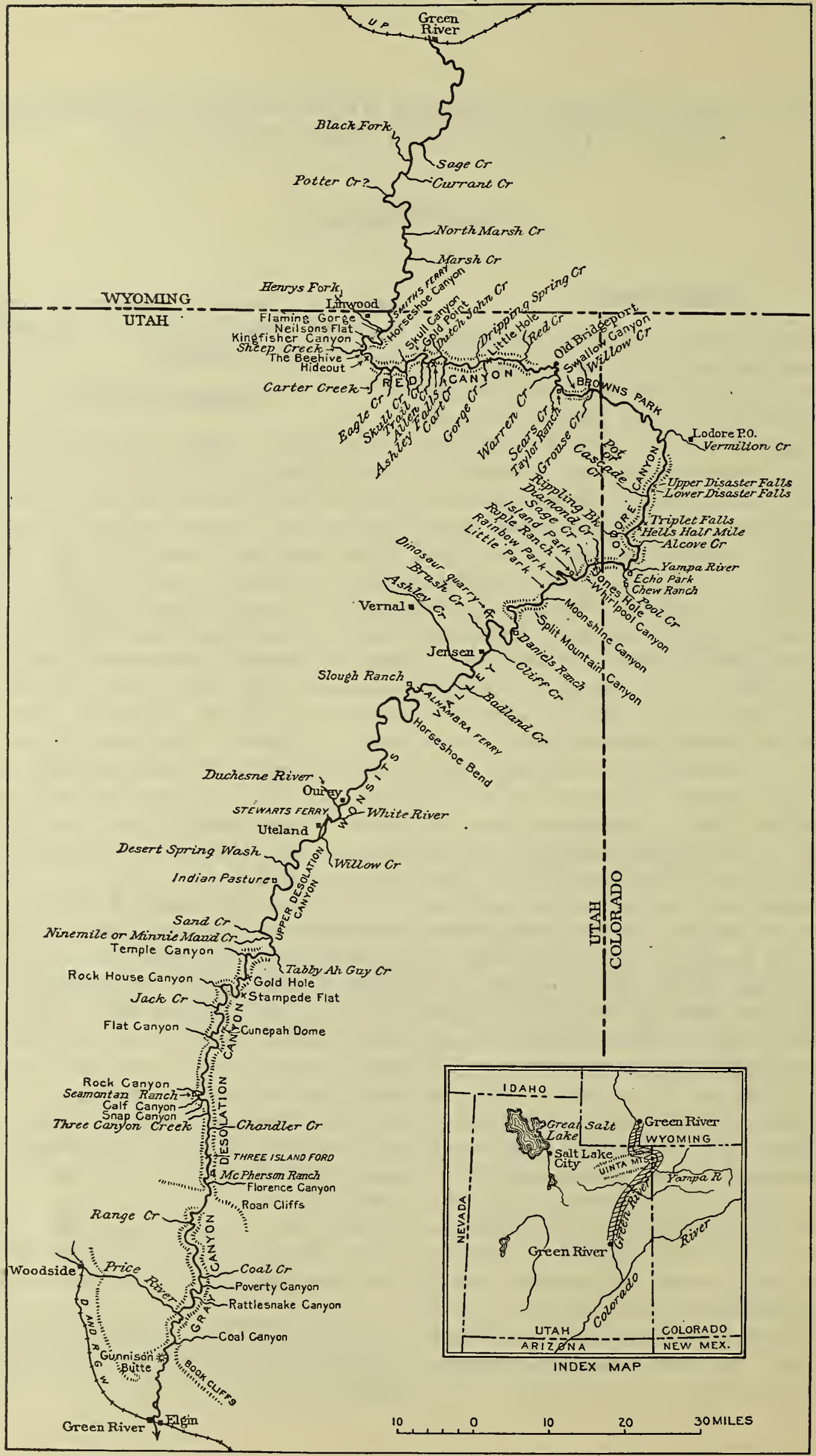

FIGURE 2.-Sketch map of Green River between Green River, Wyo., and Green River, Utah. 
shale, Mesaverde formation, and Hilliard shale (all Upper Cretaceous). These beds are not very well exposed immediately adjacent to the river, and I had no opportunity to study the exposures lying at some distance from the river bank. The Hilliard shale, viewed from a distance of perhaps a mile, appears to be a normal dark-gray marine shale such as one would expect to find in this region. Near the mouth of Henrys Fork the dip is nearly vertical.

Boars Tusk ridge.-The north flank of the Boars Tusk, a sharp ridge running southeastward from the river just below the mouth of mations, is overturned to the northeast in the lower Beckwith and Twin Creek, and appears to be nearly vertical in the basal sandstone of the Nugget and the underlying red beds. Schultz ${ }^{3}$ gives the thickness of the formations here as follows: Frontier formation, 125 feet; Aspen shale, 135 feet; Beckwith formation, 850 feet; ${ }^{4}$ Twin Creek limestone, 140 feet; Nugget sandstone, 1,000 feet; ${ }^{5}$ Ankareh shale, 300 feet; Thaynes (?) formation, 290 feet; and Woodside shale, 500 feet.

The Frontier formation here, as understood by the writer, consists of a massive brown

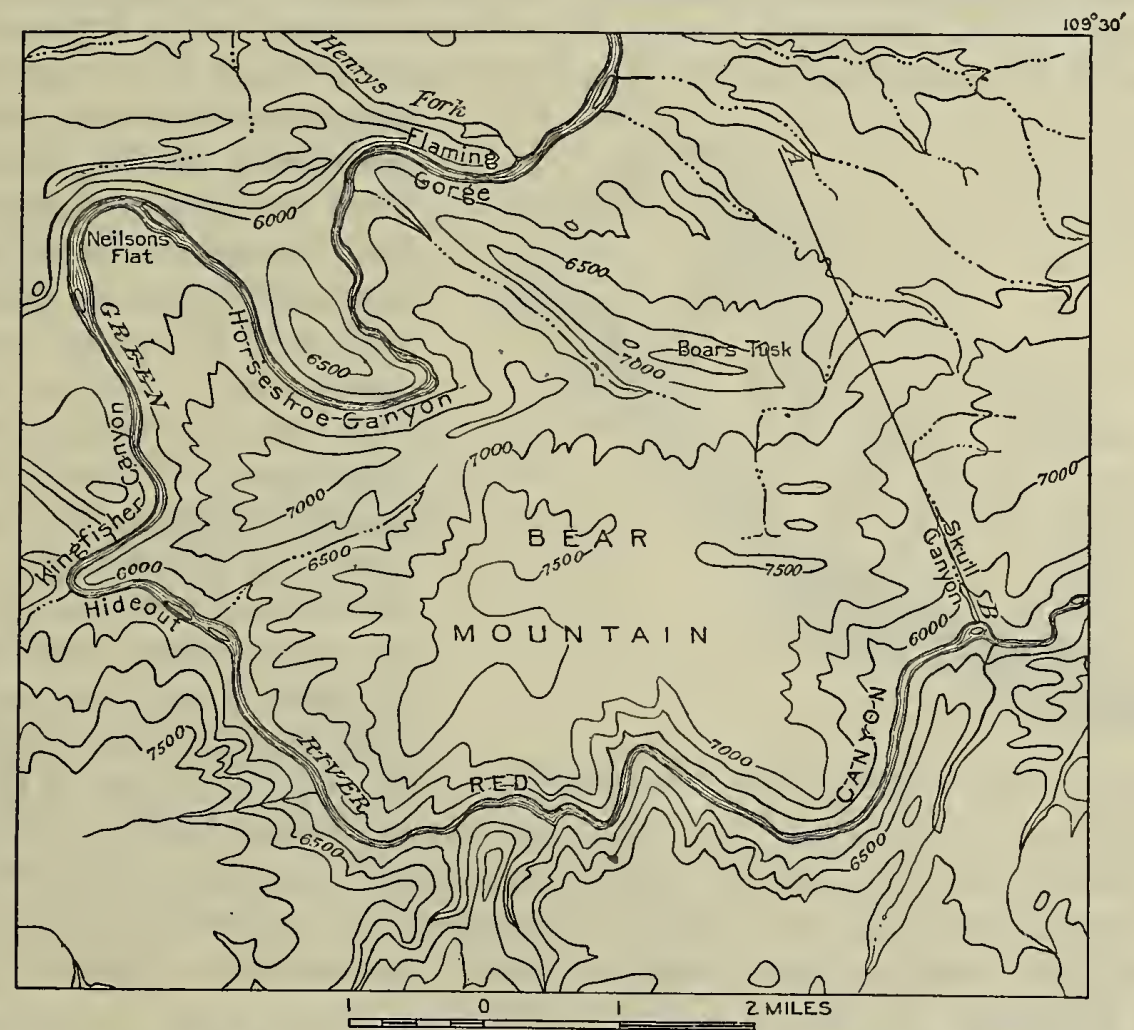

Figure 3.-Map showing Green River between the mouth of Henrys Fork and the mouth of Skullanyon, Daggett County, Utah. Shows also location of section presented in Figure 5 (line $A-R$ ). Adapted in part from Mar. Peak topographic map.

Henrys Fork, shows at the base the sandstone assigned by Schultz ${ }^{2}$ to the Frontier formation; above it, topographically, the beds assigned to the Aspen shale (Upper Cretaceous), the Beckwith formation (Jurassic and Cretaceous?), the Twin Creek limestone (Jurassic), and the Nugget sandstone (Jurassic). The south slope shows the red beds assigned by the same author ${ }^{2}$ to the Ankareh shale (Triassic?), Thaynes (?) formation (Lower Triassic), and Woodside shale (Lower Triassic). The dip is nearly vertical in the Frontier and Aspen for-

2 Schultz, A. R., Oil possibilities in and around Baxter Basin, in the Rock Springs uplift, Sweetwater County, Wyo.: U. S. Geol. Survey Bull. 702, pl. 1, fig. 3, 1920. coarse-grained cross-bedded quartzose sandstone with some thin included lenses of carbonaceous shale and, as nearly as can be determined, is about 100 feet thick. The Aspen shale is a blue-white porcelaneous platy shale containing an abundance of imprints of fish scales. It is the lithologic equivalent of the Mowry shale of the region to the east and north in Colorado and Wyoming. The thickness

a Schultz, A. R., op. cit., table opposite p. 36, pp. 73-78, and fig. 3.

4 In the table opposite p. 36 and in fig. 3 Schultz gives this thickness as 1,500 feet, but on p. 76 it is given as 850 feet, which I believe to be correct.

${ }^{5}$ In the table opposite p. 36 and in fig. 3 Schuitz gives this thickness as 1,600 feet, but on p. 78 it is given as 1,000 foet, which I believe to be correct. 
seemed to be about 225 feet, but the exposures are not entirely satisfactory, and it is possible that part of the interval should go into the Frontier formation. Immediately above the Aspen shale in the slope, but below it, in stratigraphic position, is a coarse brown conglomeratic sandstone. This sandstone is the topmost member of the Beckwith formation of Schultz, but from its lithologic constitution and its position it would be called the Cloverly formation in Wyoming or the Dakota sandstone at many other localities in the Rocky Mountain region. The pebbles in the conglomeratic parts are mostly of white and gray chert and are as much as an inch in diameter. The thickness of the sandstone is 150 feet.

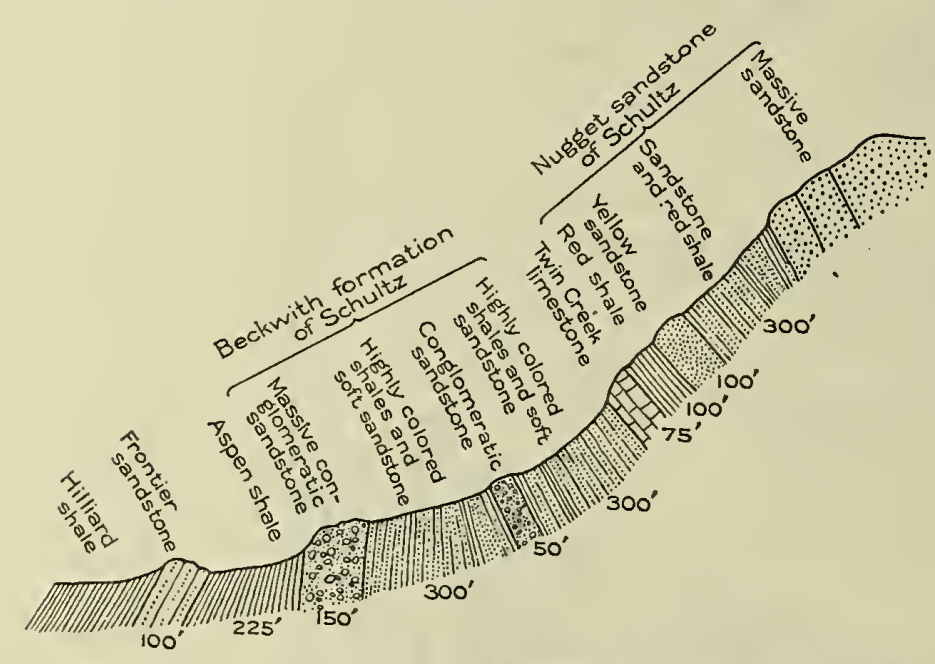

FIGURE 4.-Section of north slope of Boars Tusk ridge, Daggett County, Utah. species on careful search. This calcareous unit is the Twin Creek limestone of Schultz and is about 75 feet thick. Above the Twin Creek beds in the slope lie red shale 100 feet thick, then a yellow sandstone about 100 feet thick, then about 300 feet of beds that are not well exposed but seem to consist largely of sandstone interbedded with layers of red shale, all of which together with the overlying sandstone were referred to the Nugget sandstone by Schultz. Above these beds and constituting the comb of the ridge is the massive white, brown, or reddish sandstone forming the base of the Nugget. (See figs. 4 and 7.)

I did not examine the Nugget sandstone and older beds in Boars Tusk ridge with any care and made few notes on them. The basal member of the Nugget sandstone is a thick, massive cross-bedded sandstone that resembles both the sandstone in the lower part of the Sundance formation in Wyoming and the Jurassic sandstone of southern Utah. The red beds were not well exposed in the only place where I crossed them-the gap between Skull Canyon and the drainage north of the ridge. At this locality the red beds are cut off below by. the great Uinta fault, which extends for miles along the northern edge of the Uinta Mountain uplift. The beds on the south side of the fault are the Above the sandstone in the slope, but below $\mid$ much older beds described below as the "Uinta it stratigraphically, lies a mass of highly colored, variegated shale and soft sandstone about 300 feet thick, which strongly resembles the Morrison formation of eastern Colorado and central Wyoming. These beds form a slope and at most places are not well exposed. The next higher bed in the slope is a second conglomeratic sandstone 50 feet thick, above which more colored shale and soft sandstone, about 300 feet thick and not very well exposed at most places, constitute the basal member of Schultz's Beckwith formation. Above the colored shale last mentioned (below it stratigraphically) lie gray limestone and gray calcareous shale. Some of the limestone layers are fairly massive, but most of them are thin and platy. Rhynchonella gnathopora Meek and Ostrea strigilecula White were noted, but the beds would undoubtedly yield many more formation," the formations normally occurring between the red beds and the "Uinta formation" having been displaced by the fault. (See fig. 5.)

It seems hardly possible that the Frontier formation, the Aspen shale, and the uppermost part of the Beckwith formation of Schultz are the exact equivalents of the Frontier, Mowry, Thermopolis, and Cloverly formations in Wyoming, but the similarity of lithologic succession is striking. That the beds in the Beckwith formation of Schultz that resemble the Morrison formation are equivalent to that formation is placed beyond doubt by the occurrence of a large fauna of Morrison dinosaurs in beds at the same stratigraphic position near Jensen, Utah. The Twin Creek limestone of Schultz is beyond question equivalent to the upper, calcareous zone of the Sundance formation of 
central Wyoming. These calcareous beds with the beds below them, down probably to the base of the Nugget sandstone, I consider to represent the interval usually included in the Sundance formation in central Wyoming.

Flaming Gorge, Horseshoe Canyon, Neilsons Flat, and Kingfisher Canyon.-In Flaming Gorge the conspicuous rocks are the rim of Nugget sandstone and the slopes of red beds (Ankareh, Thaynes (?), and Woodside formations of Schultz). At the lower end of the gorge the river passes across the trough marking the outcrop of the rather soft and unresistant upper part of the Park City formation (Permian and Pennsylvanian) into the box canyon cut in the lower part of the Park City formation and the Weber sandstone (Pennsylvanian) and named by Powell Horseshoe Canyon. From Horseshoe Canyon the river passes back into the trough of Park City beds, where a low area near the river is known as Neilsons Flat. noted by Schultz. ${ }^{6}$ The beds next below the unconformity are darker in color-a brickred-and weather differently, their surface having a sort of network sculpturing due to small regularly arranged cavities, whereas the surface of the upper beds is fairly smooth. The lower beds are nearly all sandstone and are clearly the Thaynes (?) formation of Schultz. The typical Thaynes formation, ${ }^{7}$ near Park City, is essentially a calcareous formation with gray limestone and sandstone, but there is nothing of the sort to be seen here. Beneath the cliff of Thaynes (?) formation lies a long slope underlain by light brick-red sandy shale and soft sandstone and broken near the base by some harder layers that form small benches and by some gray layers interbedded with the red. This unit is evidently the Woodside shale of Schultz and corresponds in a general way to the description of the typical Woodside shale near Park City. ${ }^{8}$

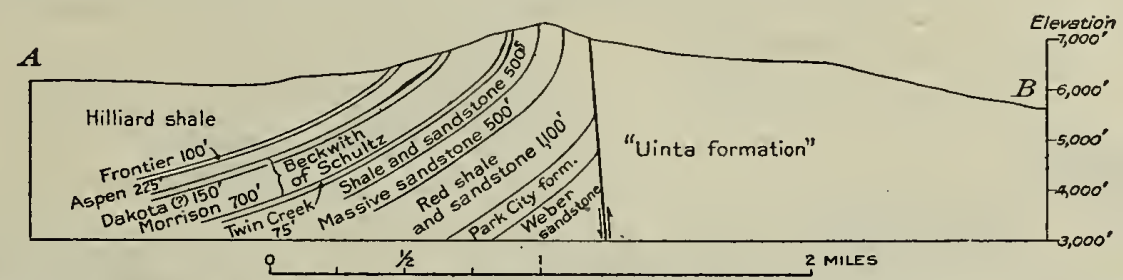

Figure 5.-Cross section of ridge east of Boars Tusk ridge, Daggett County, Utah. See Figure 3 for location.

From Neilsons Flat the river passes into a second box canyon cut in Weber sandstone and named by Powell Kingfisher Canyon. Kingfisher Canyon is cut off at its lower end by the Uinta fault mentioned above, though here the surface trace of the fault has passed over into older beds and the Weber sandstone lies in contact with the "Uinta formation." (See fig. 3.)

The area including the localities just mentioned is a geologic unit, and the geographic divisions are made by sharp turns in the river. The Nugget sandstone forms a cliff running northeastward and lying to the north and northwest of the area. Beneath it the Ankareh shale of Schultz is composed of dark salmonred sandstone and shale with a minor proportion of yellowish beds. The upper part of the formation appears to contain softer rock and forms a slope, but the lower part is harder and forms a bench. The formation is bounded at the base by a very irregular, wavy surface of erosion that I take to be the unconformity
Schultz gives the thickness of the formations as follows: Ankareh, 300 feet; Thaynes, 290 feet; Woodside, 500 feet. I did not make any measurements but believe these figures to be about right. (See fig. 6.)

Boutwell ${ }^{9}$ gives the thickness of the Ankareh formation at its typical locality near Park City as over 1,150 feet, the Thaynes formation as 1,290 feet, and the Woodside shale as 1,090 feet. If the beds assigned to these formations near Green River are really equivalent to the typical divisions near Park City, the differences between them and the typical development as described by Boutwell must be ascribed to some such change in passing eastward from Park City as occurs in southern Utah in the Moenkopi formation, also of Tri-

${ }^{6}$ Schultz, A. R. Oil possibilities in and around Baxter Basin, in the Rock Springs uplift; Sweetwater County, Wyo.: U. S. Geol. Survey Bull. 702, tables opposite pp. 24 and 36, 1920.

7 Boutwell, J. M., Geology and ore deposits of the Park City district, Utah: U. S. Geol. Survey Prof. Paper 77, pp. 55-88, 1912 ,

8 Idem, pp. 52-54.

9 Idem, pp. 52, 56, 58 . 
assic age. ${ }^{10}$ The Moenkopi formation thins eastward, and the proportion of limestone to noncalcareous beds decreases rapidly in the same direction. The Ankareh formation suggests, in its position beneath the Nugget and its unconformable relation to the underlying beds, the Jelm formation ${ }^{11}$ of southern Wyoming, which lies beneath the basal Sundance sandstone and is unconformable on the underlying Chugwater red beds. The Chugwater beds are in turn much like the combined Thaynes (?) and Woodside formations of Green River valley.

The Park City formation lies beneath the Woodside shale and is only indistinctly separated from it. It is described by Schultz ${ }^{12}$ as calcareous. It stands in cliffs along the river at most places where it is exposed. Schultz gives the thickness along Green River as 1,600 feet.

Hideout and Red Canyon.- - Hideout is a rather open area between Kingfisher Canyon and Red Canyon. It is perhaps a mile in length measured along the river and affords relatively easy access to the river on either bank. Red Canyon may be considered to extend down the river from Hideout to a point several miles below Red Creek, though it might equally well be considered to end at or above Red Creek. The height and inclination of the canyon walls varies very much-so much, in fact, that perhaps the only uniform character is the constituent rock, the mass of dark-red

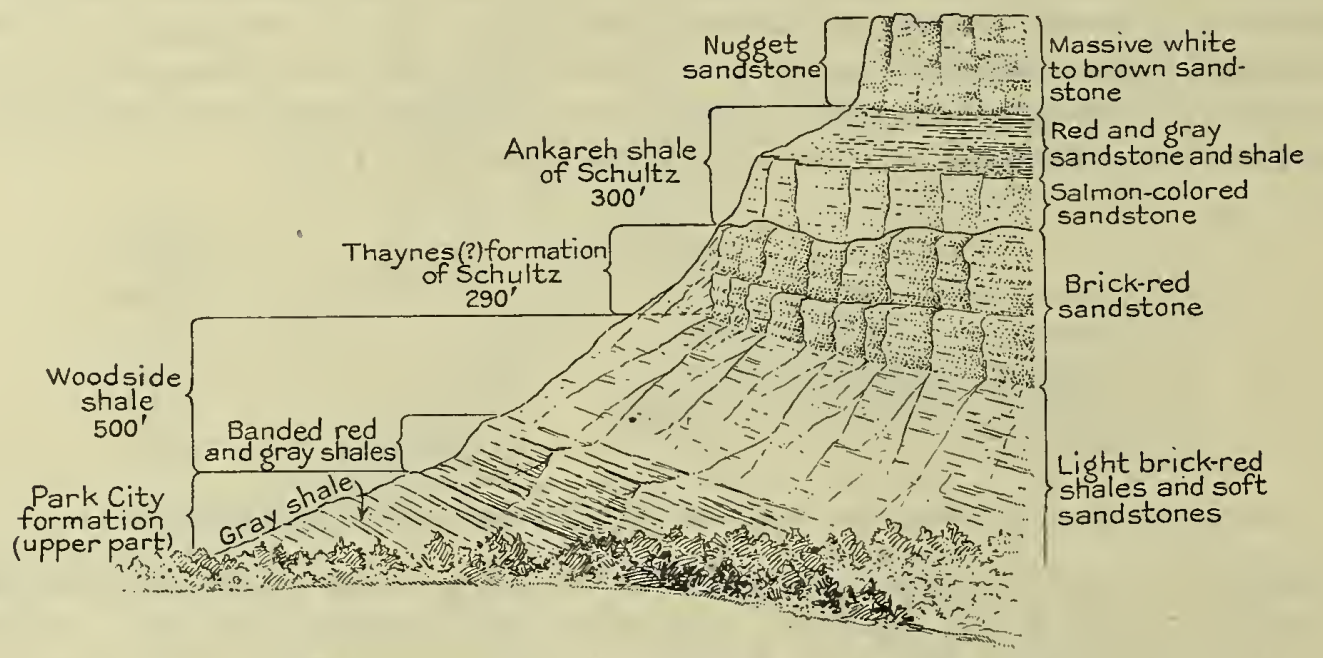

FIGURE 6.-Diagrammatic sketch of bluff northwest of Neilsons Flat, Daggett County, Utah.

containing near Flaming Gorge in the upper part a gray calcareous shale or shaly limestone 200 feet thick, underlain by a massive cherty limestone 25 feet thick, a phosphate-bearing shale, with chert nodules, 40 to 50 feet thick, and a basal member of massive limestone 100 feet thick resting unconformably on the Weber sandstone. These subdivisions are recognizable without difficulty and maintain very nearly the thicknesses given.

The Weber-sandstone is a very massive, resistant brown sandstone, probably in part

10 Reeside, J. B., jr., and Bassler, Harvey, Stratigraphic sections in southwestern Utah and northwestern Arizona: U. S. Geol. Survey Prof. Paper 129, pp. 59-61, 1922.

11 Knight, C. W., Age and origin of the red beds of southeastern Wyoming (abstract): Geol. Soc. $\Lambda$ merica Bull., vol. 28, p. 168, 1917.

12 Schultz, A. R., A geologic reconnaissance of the Uinta Mountains, northern Utah: U.S. Geol. Survey Bull. 690, p. 52, 1918; Oil possibilities in and around Baxter Basin, in the Rock Springs uplift, Sweetwater County, Wyo.: U. S. Geol. Survey Bull. 702, tables opposite pp. 24 and 36,1920 . to red-brown sediments called by Powell ${ }^{13}$ the "Uinta group" and by most later geologists the "Uinta quartzite" or "Uinta formation," though by King and Emmons mistakenly identified as Weber sandstone. The name Uinta is more correctly applied to the very much later Tertiary formation that occurs in the Uinta Basin, to the south of the mountains, but as no other acceptable name has been given to the older unit the name "Uinta formation" will be used with quotation marks for it in the present description.

The "Uinta formation," the only one exposed in Red Canyon, is a succession of deepred to maroon resistant sandstone and conglomerate, with lesser amounts of hard red shale. The sandstone is usually dense and is

13 Powcll, J. W., Report on the geology of the eastcrn portion of the Uinta Mountains, pp. 41, 61, 141, U. S. Geol. and Geog. Survcy Terr., 1876. 
in places changed to a true quartzite in which individual grains are not easily distinguished; locally the color is a deep brown. The shale at some places is greenish. The beds in the upper part of Red Canyon contain more shaly beds proportionately than those in the part farther downstream, though there are some massive beds throughout its length. The canyon walls at many places are débris-covered slopes; at others, cliffs of bare rock. Powell gives the thickness of the "Uinta group" as more than 12,000 feet, and most later writers quote his figures. I had no opportunity to estimate or measure the thickness, but it is certainly very great.

No fossils have been recorded from the "Uinta formation," and it has been assigned by various writers to the Devonian, Carboniferous, Cambrian, and pre-Cambrian. I can add nothing regarding the age of the formation except that search at many places for features that would aid in fixing the age revealed only obscure trails, mud cracks, and raindrop impressions, of no especial value for this purpose.

Browns Park and Swallow Canyon.-The open valley between Red Canyon and Lodore Canyon, called Browns Park, affords few good exposures near the river, and as it had already been mapped the party's passage through it was too rapid even to see much of those. One exposure of soft dove-gray shale or clay not far below the upper end of the park is probably late river-terrace material, though as far as lithology goes it might equally well be of Tertiary age. Other exposures of brown sandstone are probably part of the late Tertiary Browns Park formation. ${ }^{14}$ Swallow Canyon, on the south side of Browns Park, is a relatively shallow canyon cut through the "Uinta formation" by a 4-mile loop of the river which abruptly leaves the soft valley deposits to plunge into the hard sandstone beds and as abruptly returns to the valley.

Lodore Canyon.-From Browns Park the stream passes again into exposures of "Uinta formation" in the deep, narrow course of Lodore Canyon. These exposures differ in no essential respect from those in Red Canyon. The formation has perhaps fewer soft layers, and the walls stand at high angles with but

14 Powell, J. W., op. cit., pp. 40, 44, 168. $55903^{\circ}-23-2$ little débris upon them. For the first 12 miles of the canyon, approximately, no rocks except this formation are visible. Then there appears at the top of the canyon walls the first of the post-"Uinta" formations, the Lodore group of Powell. ${ }^{15}$ This gradually descends down stream until at a point near the mouth of Alcove Creek it reaches river level. Above the Lodore "group," or Lodore formation, as it would now be called, appear the beds designated by Powell "Redwall group," "Lower Aubrey group," and "Upper Aubrey group." 16 These divisions probably correspond closely to the Mississippian limestone, Pennsylvanian limestone, and combined Weber sandstone and Park City formation of Schultz. ${ }^{17}$

The Lodore formation, as I interpreted it, contains a flaggy basal sandstone of salmon color that is sharply separated from the underlying "Uinta formation" by an unconformity representing an erosion interval. ${ }^{18}$ This basal sandstone is overlain by a succession of variegated red, purplish, and green sandy shales and thin sandstones. Possibly there are some thin limestone beds at the top that should also be included in the Lodore formation, though I tentatively put all the limestones into the next higher unit. The shale unit is softer than the underlying beds and the succeeding Carboniferous limestone and makes a marked slope. The basal sandstone is about 150 feet thick and the shale unit about 300 feet thick. Powell gives 460 feet as the thickness of his Lodore "group," and the round figure of 500 feet is cited by most later writers. No fossils have been recorded from the Lodore formation but it is supposed by recent writers to be Cambrian, both from its position in the section and its resemblance to beds in the Tonto group of the Grand Canyon. The Carboniferous fossils noted by Powell on page 56 of the report cited were very probably out of place.

The beds designated by Powell "Redwall group" and "Lower Aubrey group" include in the lower part much massive cream-colored to brown cherty limestone very similar to the Madison limestone (lower Mississippian) of

15 Powell, J. W., op. cit., pp. 41, 56, 147. 16 Idem., pp. 41, 54-55, 147-149.

17 Schultz, A. R., Oil possibilities in and around Baxter Basin, in the Rock Springs uplift, Sweetwater County, Wyo.: U. S. Geol. Survey Bull. 702, table opposite p. $36,1920$. 18 Powell, J. W., op. cit., pp. 144-145. 
central Wyoming; and in the upper part a succession of red, pink, and purplish shale and sandstone and gray and pinkish limestone, all in relatively thin layers and as a mass much like the beds commonly assigned to the Amsden formation (Pennsylvanian and upper Mississippian) in central Wyoming. I estimate the thickness of the upper and lower divisions as 1,000 to 1,200 feet each.

Above the beds of Powell's "Lower Aubrey group" comes the Weber sandstone, here as in Horseshoe and Kingfisher canyons a very massive, much cross - bedded yellow - brown quartzose sandstone that rises in sheer unbroken walls for hundreds of feet.

At the extreme lower end of Lodore Canyon, just at the edge of Echo Park, a fault, visible on the right bank of the river and striking in a direction somewhat east of north, brings the lower part of Powell's "Redwall group" into contact with the extreme top of his "Lower Aubrey group." The extension of this same fault southward is clear in Mitten Park and the basin of Pool Creek. (See below.)

Echo Park, Pool Creek, and Mitten Park.Green River, on leaving Lodore Canyon, follows for some miles a course shaped like a narrow $U$ with the open end to the north. The east limb of this $U$ receives Yampa River from the east, and the bend receives Pool Creek from the south. The narrow open bottom adjacent to the mouths of these streams is Echo Park or Pat's Hole. Farther downstream, at the top of the west limb of the $U$, another small open bottom is known as Mitten Park. From Mitten Park the river passes abruptly into Whirlpool Canyon.

Echo Park is walled in by sheer cliffs of Weber sandstone, which likewise forms Steamboat Rock, the great mass that fills the area in the center of the $U$. The lower course of Pool Creek is a narrow box canyon, likewise in the Weber sandstone, though in about 2 miles the creek bed rises above it, through the Park City beds, and runs upon red beds. These red beds lie in a small basin bordered on the west by the fault mentioned above and possibly by another on the south. The Woodside shale appears to be much as on the north side of the mountains, and the Thaynes (?) about the same except for the occurrence of some heavy beds of brown sandstone. I believe that the supposed Ankareh and later beds have been removed here by erosion.

In Mitten Park the rocks are tilted to a high angle in proximity to the fault and are even overturned. The downthrow is on the east and the upthrow on the west, bringing above the river level several hundred feet of the upper part of the "Uinta formation."

I made no estimate of thicknesses in this region, though the Weber sandstone is certainly in excess of 1,000 feet.

Whirlpool Canyon.-At the upper end of Whirlpool Canyon the uppermost several hundred feet of the "Uinta formation" appears west of the fault described above. The normal succession of formations appears above it-Lodore formation, "Redwall group," and "Lower Aubrey group." The Lodore formation has about the same constitution and thickness as in Lodore Canyon; likewise the lower Madisonlike part of Powell's divisions and the upper Amsden-like part. The irregular contact of the Lodore formation on the "Uinta formation" is especially well shown. The formations dip downstream, and at the lower end of the canyon the Weber sandstone appears. It is bent sharply downward and cut off by a fault, which runs about parallel to that of the upper end, with the downthrow on the west and the upthrow on the east. ${ }^{19}$ Whirlpool Canyon therefore seems to cross an uplifted fault block, with the Mitten Park fault on the east and the Island Park fault on the west.

Island Park.-The area along the river between Whirlpool Canyon and Split Mountain Canyon is divided by the local residents and on some maps into three small parks. These are merely large bottoms separated by low ridges and are called, in order downstream, Island Park, Rainbow Park, and Little Park. The rocks of this area, often called as a whole Island Park, lie in an unsymmetrical syncline with axis plunging a little south of east and with the eastern tip truncated by the fault at the eastern edge of Island Park. The formations present extend from the Weber sandstone to the Hilliard shale, inclusive. The character of the rocks is best shown in the following section:

19 See Schultz, A. R., A geologic reconnaissance of the Uinta Mountains, northern Utah: U. S. Geol. Survey Bull. 690, pi. 5, 1918. 
Section measured in Island Park.

[See also fig. 7.]

Measured northwest of Rainbow Park.

Hilliard shale.

Frontier formation of Schultz:

Sandstone, massive, gray to yellow . . .......

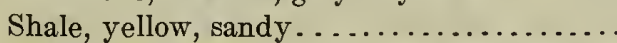

Sandstone, massive, gray to yellow.........

Shale, yellow to gray, in part sandy.........

Aspen shale of Schultz: Shale, hard, platy, bluish-white, with abundant fish scales. Ex-

actly like Mowry shale in Wyoming. . . . . . . .

Beckwith formation of Schultz:

Sandstone, massive, brown to gray, coarse, containing few lenses of pebbles the size of wheat. (Where measured the upper part of this unit is in almost direct contact with Aspen shale, but along the strike the upper 50 feet changes to very dark shale)..

Shale, brown to dark gray, with some thin beds of brown sandstone. Not as dark as might be expected at this horizon. .......

Sandstone, coarse, brown to gray. No pebbles seen .........................

Shale, variegated purple, green, gray; sandstone, soft, whitish; and sandstone, brown, hard. Contain bone fragments and gastroliths at a number of horizons. Beds change rapidly both vertically and horizontally. Possibly some of the basal beds may belong to the underlying marine Jurassic, but they did not furnish clear evidence of marine origin. Thickness calculated from topographic data...........

Measured 1 mile west of Ruple ranch.

Twin Creek formation of Schultz:

Shale, greenish gray, with layers of platy argillaceous sandstone and some lenses of soft yellow sandstone. Not sharply separated from overlying unit. Sandstone layer 10 feet above base contains Rhynchonella gnathophora Meek, Ostrea sp. undetermined, Tancredia warrenana Meek and Hayden, Trapezium? sp...............

Sandstone, blocky, light brown, fine-grained; contains Rhynchonella, Ostrea, and other fossils very poorly preserved.............

Sandstone, soft, gray-white, cream-colored to yellow, argillaceous; at most places weathers back like shale, at others stands out as ledges; contains lenses of greenish shale. No fossils seen. . . . . . . . . . . . . . . . .

Shale, greenish gray, with thin layers of sandy brownish limestone and nodules of dense blue limestone. Contains Cidaris? sp., bryozoan, Parallelodon? n. sp., Pinna sp., Eumicrotis curta (Hall), Ostrea strigilecula White, Cardinia? n. sp., Trigonia quadrangularis Hall and Whitfield, Camptonectes platessiformis White, Modiola pertenuis Meek and Hayden, Pleuromya new-
Twin Creek formation of Schultz-Continued. toni Whitfield, Astarte packardi White, Tancredia? inornata Meek and Hayden, Dosinia jurassica Whitfield, Quenstedticeras? hoveyi Reeside, Cardioceras cf. C. cordiforme (Meek and Hayden), Cardioceras sp., Belemnites densus Meek and Hayden................

Nugget sandstone of Schultz:

Sandstone, platy, gray to cream-colored, with thin shale layers. Grades into overlying beds.........................

Sandstone, massive, cream-colored, crossbedded............................

Sandstone, platy, gray, interleaved with thin layers of green, gray, and purple shale. The lower part contains clay-pellet conglomerates, and the base is a sinuous line. Probably no unconformity of much magnitude, as both these beds and the underlying beds are shallow-water deposits.

Sandstone, massive, cream-colored to brown, cross-bedded, in a single bed. Crossbedding seems to be of the current type..

\section{Measured in Little Park.}

Shale, brick-red with some gray streaks..... Sandstone, gray to yellow, locally salmoncolored, cross-bedded, very massive.......

Sandstone and shale, alternating in thin beds, red and white......................

Ankareh shale of Schultz:

Shale, sandy, red with some white streaks and gray layers.....................

Sandstone, salmon-colored, massive, medium

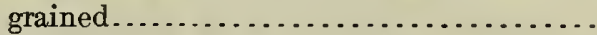

Shale and soft sandstone, mostly brick-red..

Grit, coarse, white, yellow, and pink, with lenses of pebbles of quartz and chert 1 inch or less in diameter; basal part has pebbles as much as 2 inches in diameter......... Unconformity.

Thaynes (?) and Woodside formations of Schultz: Shale and sandstone, brick-red, without any prominent subdivisions; estimated at....... 1,000 Park City formation.

Split Mountain Canyon.--The rocks exposed in Split Mountain Canyon (sometimes locally called Black Mountain Canyon) form a sharp unsymmetrical anticline whose axis runs about due west. The river enters the canyon at right angles to the strike of the rocks on the north limb but on reaching the axis of the fold runs parallel to it for about 5 miles, then at right angles to the strike across the south limb. The upper end of the canyon is in Weber sandstone, but the dip is steep and soon brings up the upper part of the "Lower Aubrey group" of Powell (Amsden-like beds) and in places along the axis Powell's "Redwall group" (Madison-like beds). On the south 
limb the reverse succession is present, and the canyon ends at the top of the Weber sandstone.

Wonsits Valley.-The name Wonsits Valley was applied by Powell ${ }^{20}$ to the region extending from the lower end of Split Mountain Canyon to the mouth of Duchesne River. It is here extended arbitrarily southwestward to include the valley as far as the mouth of Willow Creek.

Immediately following the Weber sandstone at the lower end of Split Mountain Canyon comes a succession of red beds, Nugget sandstone, etc., nearly identical with that in Island Park. These beds dip very steeply but are not as well exposed near the river as in Island Park. Owing to the steep dip the river passes through the older beds in a short distance and then runs upon the Cretaceous a considerable distance, but the exposures are rather poor because of the abundance of river-terrace material. Along this part of the river a number of attempts have been made to exploit the river terraces for placer gold, but they have not yet been wholly successful.

At a point about 6 miles above Jensen the river approaches closely the outcrops of the preCretaceous rocks. Near this point the Carnegie Museum of Pittsburgh, $\mathrm{Pa}$., has for years been taking dinosaur remains from a quarry in beds of Morrison age. A stratigraphic section in the neighborhood of the quarry is as follows:

Section measured at Carnegie Museum dinosaur quarry, above Jensen.

[See also fig. 7.]

River-terrace materials, underlain by Hilliard shale. Frontier formation of Schultz:

Sandstone, fairly coarse, gray to brown, crossbedded.............................

Shale, yellow, sandy, with thin layers of gray sandstone..........................

Aspen shale of Schultz:

Shale, bluish gray, hard, platy; contains many fish scales.............................

Shale, yellowish, sandy...............

Beckwith formation of Schultz:

Sandstone, gray to brown, locally weathering pink, coarse, conglomeratic, cross-bedded ...

Shale, rusty brown and drab...............

Sandstone, gray to brown, in thin beds........

Shale, rusty brown and drab................

Sandstone, ripple-marked, coarse, cross-bedded, brown to gray; rusty in places. This bed seems to be variable in thickness and may even be absent a short distance to the west..

${ }^{20}$ Powell, J. W., Map of Green River from the Union Pacific Railroad to the mouth of White River, 1873; Exploration of the Colorado River of the West and its tributaries, explored in $1869,1870,1871$; and 1872, p. $44,1875$.
Beckwith formation of Schultz-Continued.

Shale, gray, violet, and greenish, with lenses of greenish argillaceous sandstone, grit, and conglomerate that weather to a chocolatebrown; highly variable unit...............

Sandstone, greenish, conglomeratic; weathers brown. Horizon of dinosaur quarry........

Shales and sandstone, variegated; like second unit above..........................

Twin Creek formation of Schultz:

Sandstone, fine grained, fissile, beautifully ripple marked and rain pitted, greenish gray, with considerable interbedded shale. Some layers contain Ostrea sp..................

Sandstone, platy, ripple marked, gray, fine grained; contains Rhynchonella gnathophora Meek and Tancredia warrenana Meek and Hayden...........................

Shale, greenish gray, with some platy sandstone of same color......................

Sandstone, brown, limy; contains Ostrea strigilecula................................

Shale, dark gray, almost black, containing dense blue limestone in concretions................

Limestone, gray, coarse, sandy; contains Eumicrotis curta (Hall), Ostrea strigilecula White, Camptonectes platessiformis White, Astarte packardi White, Tancredia? inornata Meek and Hayden, Tancredia sp., Dosinia jurassica Whitfield?, Cardioceras russelli Reeside, Cardioceras hyatti Reeside, Cardioceras cordiforme Meek and Hayden, Cardioceras aff. C. wyomingense Reeside, Cardioceras sp.............

Shale, greenish gray, with limestone in nodules and containing Ostrea strigilecula White and Eumicrotis curta (Hall).................. Nugget sandstone of Schultz:

Sandstone, very massive, cross-bedded, medium grained, yellow to gray..............

Shale and platy sandstone, yellow to gray.....

Sandstone, massive, gray to yellow, crossbedded, medium grained.................

Shale, variegated, gray and brick-red.........

Sandstone, very massive, yellow to gray; forms here an impassable ridge; must be some hundreds of feet thick.

For a short distance below the dinosaur quarry there are very good exposures of

Feet. Hilliard shale close to the river, but over much of the way to Jensen the exposures are poor. The rocks lie in a syncline plunging to the west, as shown by Gale ${ }^{21}$ and Schultz. ${ }^{22}$ An anticline, also plunging westward and with its axis passing close to Jensen, brings up Frontier sandstone just east of the town. Downstream from Jensen the river passes through higher and higher beds. About 6 miles southwest of Jensen sandstone and shale containing

${ }^{21}$ Gale, H. S., Coal fields of northwestern Colorado and northeastern Utah: U. S. Geol. Survey Bull. 415, pl. 21, 1910.

${ }_{22}$ Schultz, $\Lambda$. R., A geologic reconnaissance of the Uinta Mountains, northern Utah: U. S. Geol. Survey Bull. 690, pl. 5, 1916. 
many red beds appear. These beds are / dip northward. From that point on to a relatively soft and lack the hard sandstones locality some distance above Ouray only these present in the Wasatch. I take them to be red beds are visible, but at this locality gray the Tertiary beds assigned to the Bridger beds appear at river level and the red element formation (middle and upper Eocene) and is less striking.

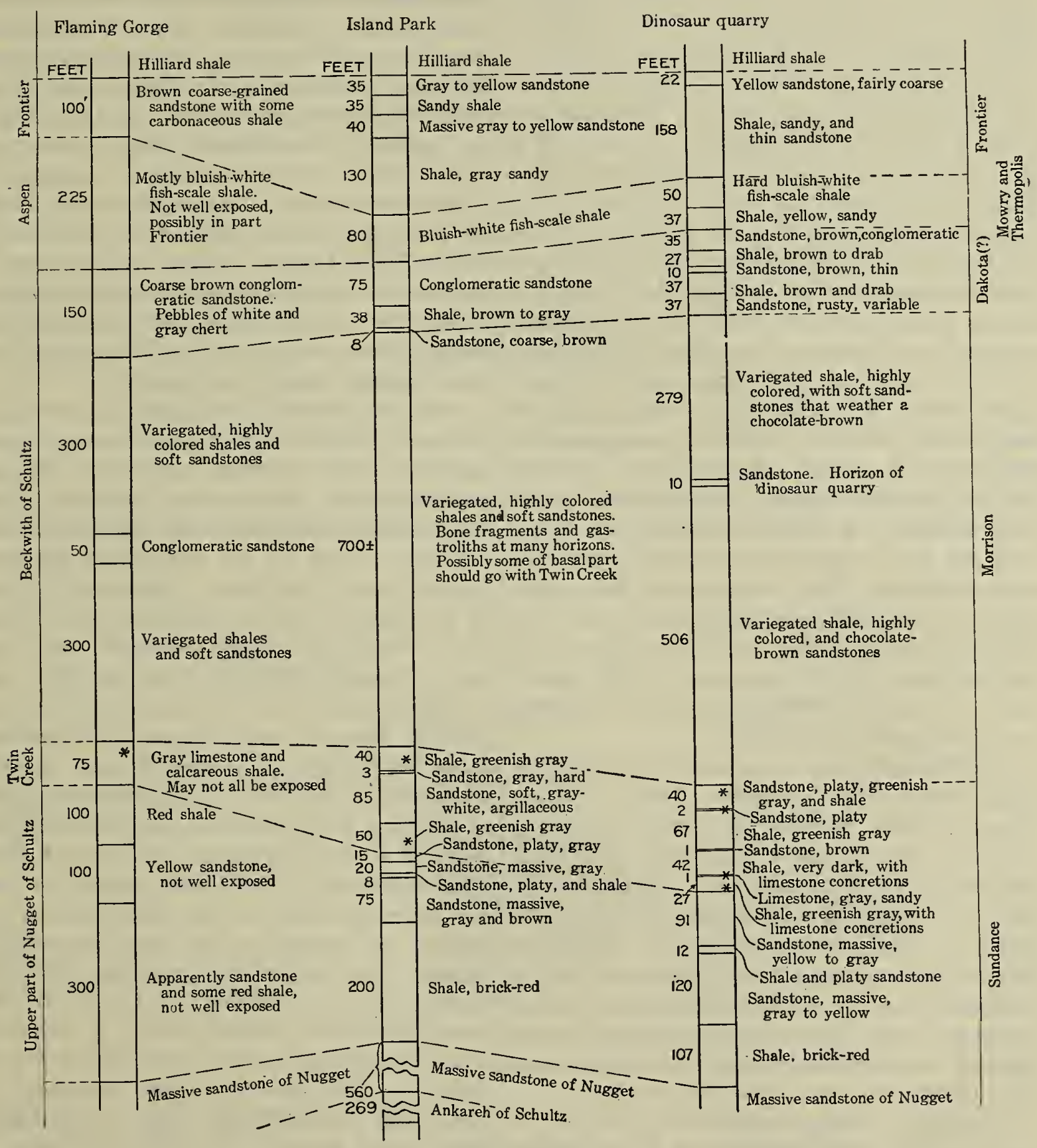

* Marine Jurassic fossils

FIGURE 7.-Diagram showing correlation of sections near Flaming Gorge, Daggett County, and in Island Park and near the Carnegie Museum dinosaur quarry, Uinta County, Utah.

Uinta formation (upper Eocene). This is the Upper Desolation Canyon.-The name Desoreal Uinta formation. These beds have a lation Canyon was applied by Powell ${ }^{23}$ to the south dip at their northern edge. Farther stretch of valley from a point somewhere in the downstream they lie practically flat, but about at the neck of Horseshoe Bend they begin to

23 Powell, J. W., Exploration of the Colorado River of the West and its tributaries, explored in $1869,1870,1871$, and 1872 , pp. 46-50, 1875. 
neighborhood of Indian Pasture downstream to the Roan Cliffs. For the present description the stretch of valley between Willow Creek and Minnie Maud Creek is taken arbitrarily as Upper Desolation Canyon, though it is much less a canyon than a sharply limited valley, and the valley below it to the Roan Cliffs is taken as Desolation Canyon proper.

Near the mouth of Willow Creek much sandstone is present in short lenses. The shale between and around the sandstone lenses is of a sort of mauve color, and the sandstones themselves a coffee-brown. The whole mass has a purple tone when seen in the distance. Near the mouth of Desert Spring Wash the purple beds are replaced in part by gray and yellowish beds. The dip is low, but the replacement is thought to be due to the rising of older beds to river level. A few miles below Desert Spring Wash the walls of the valley are all of gray and yellowish beds of unmistakable Green River aspect. Sandstone is present but only in short lenses, and the bulk of the rock is shale. At Indian Pasture the shaly beds are very conspicuous and the slopes look as if all shale. The change from the purple beds to the gray beds appears to mark the change from the Bridger and Uinta formations to the Green River formation. There seems to be no break. I did not estimate the thickness of the purple-red beds.

Winchester ${ }^{24}$ places the base of the Bridger beds some distance above Desert Spring Wash-in fact, beyond the area covered by his map-but he must have had some such distinction in mind as that stated above. The zone of rich oil shale appears at river level about 3 miles above the mouth of Minnie Maud Creek, according to Winchester, and is mapped by him along the walls of the canyon for many miles below, rising southward until high up on the walls it turns to the east and west somewhere near Chandler Creek.

Desolation Canyon.-Desolation Canyon is here considered to extend from Minnie Maud Creek to the Roan Cliffs below the McPherson ranch.

Near Minnie Maud Creek the walls of the canyon appear to be largely shale, gray to

21 Winchester, D. E., Oil shale of the Uinta Basin, northeastern Utah: U.S. Geol. Survey Bull. 691, pl. 12, 1919 . yellowish, with only a minor amount of sandstone, but downstream some miles near Tabby Ah Guy Canyon, much more sandstone appears-fine grained, yellow to brown, platy. The sandstone layers in weathered faces are often masked by débris but in clean vertical faces are very evident. Some of the sandstone has probably come in by lateral change from shale, some of it by rising above river level. Near Temple Canyon the lowest beds are nearly all sandstone, yellow and rusty brown, with a minor amount of maroon and greenish-gray shale. Above these sandy beds the shaly gray Green River beds like those of Minnie Maud Canyon appear, but they are so high on the canyon wall that, considering the low dip, it is very unlikely that they could have simply risen. I believe that there has been some lateral change in lithology.

Near the mouth of Jack Creek the rocks for perhaps 1,000 feet above the river are brown sandstone with a minor amount of red and greenish shale. Above these beds are oolitic cream-colored limestone and light shale and sandstone, such as are present in the more typical Green River beds. How much, if any, of the mass of brown sandstone and colored shale are Green River formation and how much Wasatch formation I am unable to say.

Down near the river level at Jack Creek some striking deep-red beds appear. Downstream these red beds near the river become progressively thicker, and there is a fairly sharp plane of division between them and the overlying mass of brown sandstone and colored shale. The distinction is not ideally sharp, as some red coloring occurs in the rocks above, and there is no evidence of any break in sedimentation. The top of the marked red series might well be considered the top of the Wasatch formation, though here, as has been noted at other places in the region by various observers; the position of the boundary between the Wasatch and Green River formations offers ground for wide difference of opinion. These reddish beds make up more and more of the canyon walls downstream until they finally include practically all the rock visible from the river. Near Three Canyon Creek there is much conglomerate of small chert pebbles in the fallen blocks along the 
river, though I did not see the rock in place. Just below the McPherson ranch at river level appear gray shale, thin brown sandstone, and dark fresh-water limestone crowded with. Viviparus, Unio, and other fossils. Beneath these beds are gray shale with streaks of red and then plain gray shale and brown sandstone. I supposed the red and gray shales associated with the fresh-water limestone to be the base of the Wasatch and the gray shale and brown sandstone beneath them to be the Mesaverde formation of the region. The outcrop of the red beds turns away from the river here to form the Roan Cliffs, and Gray Canyon begins.

Gray Canyon.-Gray Canyon is cut in a succession of alternating massive brown sandstone and gray shale-the Mesaverde formation of the region. Coal beds are present in the lower part of this series, but I did not have time to locate any definitely. There is little change in character of the rocks above the end of the canyon, where the outcrops of the sandstones turn off to the east and west to form the Book Cliffs, and the river runs through lowlands of Mancos shale.

Comparison of the series of lithologic units recognized in Green River valley with those in southwestern Utah and central Wyoming.

\begin{tabular}{|c|c|c|c|c|c|}
\hline Age. & Southwestern Utah. & Green River valley. & \multicolumn{2}{|c|}{ Central Wyoming. } & Note. \\
\hline \multirow{3}{*}{$\begin{array}{l}\text { T ert i a r y } \\
\text { (Eocene). }\end{array}$} & \multirow{3}{*}{ Pink Cliff series of Dutton. } & $\begin{array}{l}\text { Uinta formation. } \\
\text { Bridger formation. }\end{array}$ & \multicolumn{2}{|c|}{$\begin{array}{l}\text { Uinta formation. } \\
\text { Bridger formation. }\end{array}$} & \multirow{5}{*}{$(a)$} \\
\hline & & Green River formation. & \multirow{2}{*}{$\begin{array}{l}\text { Wasatch } \\
\text { formation. }\end{array}$} & \multirow[t]{2}{*}{$\begin{array}{l}\text { Wind River } \\
\text { formation. }\end{array}$} & \\
\hline & & Wasatch formation. & & & \\
\hline & & "Post-Laramie" formation. & \multicolumn{2}{|c|}{ Fort Union formation. } & \\
\hline & & "Laramie" formation. & \multicolumn{2}{|c|}{ Lance formation. } & \\
\hline \multirow{5}{*}{ Cretaceous. } & \multirow{4}{*}{$\begin{array}{l}\text { Shales and sandstones vari- } \\
\text { ously named.e }\end{array}$} & Lewis shale. & \multicolumn{2}{|l|}{ Lewis shale. } & (c) \\
\hline & & Mesaverde formation. & \multicolumn{2}{|c|}{ Mesaverde formation. } & $(d)$ \\
\hline & & Hilliard shale. & \multicolumn{2}{|c|}{$\begin{array}{l}\text { Steele shale. } \\
\text { Niobrara formation. } \\
\text { Carlile shale. }\end{array}$} & \\
\hline & & Frontier formation of Schultz. & \multicolumn{2}{|c|}{ Frontier formation. } & $(f)$ \\
\hline & & Aspen shale of Schultz. & \multicolumn{2}{|c|}{$\begin{array}{l}\text { Mowry shale. } \\
\text { Thermopolis shale. }\end{array}$} & $(g)$ \\
\hline
\end{tabular}

(See footnotes on pp. 48, 49.)
COMPARISON OF THE LITHOLOGIC SUCCESSION IN GREEN RIVER VALLEY, SOUTHWESTERN UTAH, AND CENTRAL WYOMING.

The lithologic succession in Green River valley affords an interesting comparison with that of southwestern Utah and that of central Wyoming. In general, the information available would not justify a statement that the units compared are strictly chronologic equivalents, for in the greater parts of the respective stratigraphic columns close paleontologic correlations are not possible. A similarity in the succession of lithologic units may be pointed out, however. The thicknesses of the individual lithologic units compared with one another may differ greatly, owing to differences in the length of the time interval represented by the units compared or to differences in the contemporaneous rate of deposition in the respective areas or to both causes at once.

It has seemed the best method to make such a comparison by arranging the names in current use in three vertical columns with horizontal lines including the units compared and with such comment as may be made appended as notes. 政 
Comparison of the series of lithologic units recognized in Green River valley with those in southwestern Utah and central Wyoming-Continued.

\begin{tabular}{|c|c|c|c|c|c|c|}
\hline Age. & \multicolumn{2}{|c|}{ Southwestern Utah. } & \multicolumn{2}{|c|}{ Green River valley. } & Central Wyoming. & Note. \\
\hline $\begin{array}{l}\text { Cretaceous. } \\
\text { Cretaceou......... } \\
\text { Cretas? }\end{array}$ & \multicolumn{2}{|c|}{$\begin{array}{l}\text { Sandstone. } \\
\text { Variegated shale. }\end{array}$} & $\begin{array}{l}\text { Beckwith for- } \\
\text { mation of } \\
\text { Schultz. }\end{array}$ & $\begin{array}{l}\text { Dakota(?) for- } \\
\text { mation. } \\
\text { Morrison for- } \\
\text { mation. }\end{array}$ & $\begin{array}{l}\text { Cloverly formation. } \\
\text { Morrison formation. }\end{array}$ & $(h)$ \\
\hline \multirow{2}{*}{ Jurassic. } & \multicolumn{2}{|c|}{ Marine Upper Jurassic. } & \multicolumn{2}{|c|}{$\begin{array}{l}\text { Twin Creek limestone of } \\
\text { Schultz. }\end{array}$} & \multirow{2}{*}{ Sundance formation. } & \\
\hline & $\begin{array}{l}\text { White Cliff sa } \\
\text { Vermilion Cli }\end{array}$ & $\begin{array}{l}\text { dstone. } \\
\text { sandstone. }\end{array}$ & \multicolumn{2}{|c|}{ Nugget sandstone of Schultz. } & & \\
\hline \multirow{2}{*}{ Triassic. } & \multicolumn{2}{|c|}{$\begin{array}{l}\text { Chinle formation. } \\
\text { Shinarump conglomerate. }\end{array}$} & \multicolumn{2}{|c|}{ Ankareh shale of Schultz. } & Jelm formation. & $(j)$ \\
\hline & \multicolumn{2}{|c|}{ Moenkopi formation. } & \multicolumn{2}{|c|}{$\begin{array}{l}\text { Thaynes(?) formation of } \\
\text { Schultz. } \\
\text { Woodside shale of Schultz. }\end{array}$} & Chugwater formation. & $(k)$ \\
\hline Permian. & \multicolumn{2}{|c|}{$\begin{array}{l}\text { Kaibab limestone. } \\
\text { Coconino sandstone. } \\
\text { Hermit shale. }\end{array}$} & \multirow{2}{*}{\multicolumn{2}{|c|}{ Park City formation. }} & Phosphoria formation. & $(l)$ \\
\hline \multirow{3}{*}{$\begin{array}{l}\text { P e n n s y l- } \\
\text { vanian. }\end{array}$} & \multirow{3}{*}{\multicolumn{2}{|c|}{ Supai formation. }} & & & Absent(?). & \\
\hline & & & \multicolumn{2}{|l|}{ Weber sandstone. } & Tensleep sandstone. & $(m)$ \\
\hline & & & \multicolumn{2}{|c|}{ Pennsylvanian limestone. } & Amsden formation. & $(n)$ \\
\hline Mississippian. & \multicolumn{2}{|c|}{ Redwall limestone. } & \multicolumn{2}{|c|}{ Mississippian limestone. } & Madison limestone. & \\
\hline \multirow{3}{*}{ Cambrian. } & \multirow{3}{*}{ Tonto group. } & $\begin{array}{l}\text { Muav lime- } \\
\text { stone. }\end{array}$ & \multirow{3}{*}{ Lodore formation. } & $(?)$ & Gallatin limestone. & \multirow{3}{*}{$(0)$} \\
\hline & & $\begin{array}{l}\text { Bright Angel } \\
\text { shale. }\end{array}$ & & Shale. & Gros Ventre shale. & \\
\hline & & $\begin{array}{l}\text { Tapeats sand- } \\
\text { stone. }\end{array}$ & & Sandstone. & Flathead quartzite. & \\
\hline $\begin{array}{l}\text { Pre-Ca m - } \\
\text { brian. }\end{array}$ & \multicolumn{2}{|l|}{ Pre-Cambrian. } & \multicolumn{2}{|c|}{ "Uinta formation." } & Pre-Cambrian. & $(p)$ \\
\hline
\end{tabular}

$a$ The exact equivalent in time of the Pink Cliff series of Dutton is uncertain, but it probably represents some part of the Wasatch formation with possibly some later beds. The Green River formation and the Wind River have little in common except stratigraphic position; it is also probable that the Wasatch and Wind River formations are in part contemporary.

$b$ The "post-Laramie" formation and the Fort Union formation, besides having a similar stratigraphic position, contain the Fort Union flora. The "Laramie" formation contains the Laramie flora and the Lance formation the Fort Union flora and are supposed on that ground to differ in age. Beds older than Dutton's Pink Cliff series and younger than Cretaceous are not known in southwestern Utah.

c The Lewis shale is a somewhat doubtful unit on Green River. There is no well-defined shale unit between the Wasatch beds of the Roan Cliffs and the Mesaverde forma- 
tion of the Book Cliffs, south of the Uinta Mountains, that could be called Lewis shale. North of the mountains such a unit is mentioned by Gale (U. S. Geol. Survey Bull. 341 , p. 310, 1909), and by Schultz (U. S. Geol. Survey Bull. 702, fig. 3, 1920), but no description is given. A correlation of the Lewis shale of the Green River region with that of central Wyoming, and of either with the typical Lewis shale in southwestern Colorado is simply a loose grouping of large shale units of upper Montana age and does not imply identity in time of deposition.

$d$ It is not known that the Mesaverde formation of the Book Cliffs occupies the same time interval as the Mesaverde formation north of the Uinta Mountains, nor that either is the same as the Mesaverde formation of central Wyoming or of the typical region in southwestern Colorado. This name, like Lewis, has been loosely used and is made to apply practically to any coal-bearing formation within the Montana group.

$e$ The Upper Cretaceous deposits of southern Utah are variable in constitution and have been classified differently by different geologists. Much still remains to be learned, and I do not venture to make detailed correlations. There are beds that in a loose way might be called Frontier, others that might be called Mesaverde, and still others that may require other names.

$f$ The Frontier formation of the Green River region is a thin sandstone unit very low in the Colorado group. It can hardly be really the same as the much thicker Frontier formation of other areas except under the loose application of the name to any sandy unit in the lower part of the Colorado group.

$g$ The Aspen shale on Green River has exactly the lithologic character of the Mowry shale of Wyoming but is very thin and rests almost directly on the preceding sandstone (Dakota?) without any suggestion of an intervening shale like the Thermopolis shale.

$h$ The Beckwith formation as delimited by Schultz on Green River contains as its upper member a conglomeratic sandstone that would certainly be mapped as Cloverly formation in Wyoming or Dakota sandstone in Colorado. Whether it is equivalent only to the Dakota sandstone proper or contains also, like the Cloverly formation, beds of probable Lower Cretaceous age, can not be determined in the absence of fossils. The Beckwith beneath this upper sandstone contains three members which together seem to me to be the Morrison formation of Colorado and Wyoming. Schultz offers two different correlations for his Beckwith formation. In one (U. S. Geol. Survey Bull. 702, tables opposite pp. 36 and 82, 1920) he indicates that the Dakota sandstone and Cloverly formation are both probably absent and that the Beckwith formation is all Morrison in age. In the second (idem, pp. 75-77) he expresses the belief that the upper sandstone is equivalent to the Dakota sandstone of some regions and upper Cloverly of others, that the upper shale and middle conglomerate are equivalent to the middle and lower parts of the Cloverly formation, and that the lower shale alone is Morrison. The position of the dinosaur fauna near Jensen and the lithology of the Cloverly formation, so far as I know it, are both against the correlation of the two middle members with the Cloverly formation. It seems also very doubtful to me whether the Beckwith formation of the
Green River region is really comparable to the beds to which the name Beckwith is applied farther west in Utah and in Idaho.

$i \mathrm{~W}$. T. Lee, in a paper now awaiting publication, has adduced abundant evidence to indicate that the Sundance formation of Wyoming, as usually defined, contains in the lower part the equivalent of the Nugget sandstone of the Green River region and of the thick Jurassic sandstone unit of southern Utah believed to include the White Cliff and Vermilion Cliff sandstones. Some writers on Wyoming stratigraphy have included the sandstone in the upper part of the Chugwater formation, but its structural relations ally it more with the overlying than the underlying beds. The Twin Creek limestone of the Green River region is the lithologic and faunal equivalent of the calcareous beds in the upper part of the Sundance. It is very likely that the Twin Creek formation of the Green River region is equivalent to only a small part of the beds to which the name was originally applied. No evidence of any other marine Jurassic formation than the Sundance was observed on Green River.

$j$ The correlation suggested by stratigraphic position and structural relations between the Shinarump and Chinle formations, the Ankareh shale of Schultz, and the Jelm formation is largely conjectural. All three are separated from the preceding beds by an unconformity. The Shinarump is regarded as probably Upper Triassic; the Chinle and Jelm contain vertebrate remains of Upper Triassic age; the Ankareh formation in the typical region contains in the lower part marine invertebrates of Lower Triassic age. Whether the Ankareh formation of the Green River region is the same as the typical Ankareh may well be questioned.

$k$ A correlation of the Moenkopi formation and the Woodside and Thaynes (?) formations of the Green River valley rests on the assumption that the latter beds are really the equivalent of the marine Lower Triassic formations of the same names that occur in the western Uinta region. It seems to me that the assumption is very probably valid, at least in a broad sense, even though continuous tracing between the two regions is not possible. The relation of the Chugwater formation to those just named is more doubtful, though the presence of a marine limestone in the upper part of the Chugwater is difficult to account for except as an eastward extension of the marine Lower Triassic strata. Another point of difference is that the Moenkopi formation is unconformable on the preceding beds, whereas the Woodside and Chugwater formations appear to be conformable.

$l$ The equivalence of the Kaibab limestone, Coconino sandstone, and Hermit shale on the one hand and the Park City formation on the other is not supported by direct evidence. The Coconino and Hermit are placed in the Permian on the basis of fossil plants in the Hermit formation and an unconformity beneath it. The Kaibab limestone has a marine fauna of Permian age, and so has the Park City formation, in its upper (Phosphoria) part, but there are very few species in common. It is possible that the upper (Phosphoria) part of the Park City formation may be entirely later than the Kaibab limestone, though still Permian, as the Kaibab is followed by an unconformity and the upper part of the Park City is 
believed to be conformable with the succeeding beds. An unconformity is known in places in southeastern Idaho at the base of the Phosphoria formation.

$m$ The Tensleep sandstone, Weber sandstone, and Supai formation are somewhat variable sandy formations that in some phases are very much alike and in others quite different. They are assigned to the late Pennsylvanian (Supai, possibly also including Permian) and probably do not differ greatly in age.

$n$ The Redwall limestone, as originally defined from its occurence in northern Arizona, contained beds of both Pennsylvanian and Mississippian age, but in recent classifications the Pennsylvanian part has been added to the Supai formation. In southern Utah a considerable thickness of calcareous strata beneath the sandy beds assigned to the Supai formation contains Pennsylvanian fossils.
It is possible also that there are in Green River valley beds of upper Mississippian age, which in Wyoming in places occur in the lower part of the Amsden formation and above the Madison limestone (lower Mississippian).

o There is no specific evidence for correlating the Lodore formation with either the Tonto group or the Flathead, Gros Ventre, and Gallatin formations of central Wyoming. All three have a sandstone at the base followed by shales, the gross lithologic features of which are similar. If there is any limestone in the upper part of the Lodore formation, its analogy to the Tonto and Deadwood would be complete. In the field I considered any limestone beds to belong to the overlying Carboniferous, but I may have been mistaken.

$p$ There is no specific evidence to show that the "Uinta formation" is Cambrian nor that it is pre-Cambrian. 


$$
\text { - }
$$



Please do not destroy or throw away this publication. If you have no further use

for it write to the Geological Survey at Washington and ask for a frank to return it

DEPARTMENT OF THE INTERIOR

Habert Work, Secretary

U. S. GEOLOGICAL SURVEY

George Otis Smith, Director

Professional PAPER 153

\section{STUDIES OF BASIN-RANGE STRUGTURE}

BY

GROVE KARL GILBERT

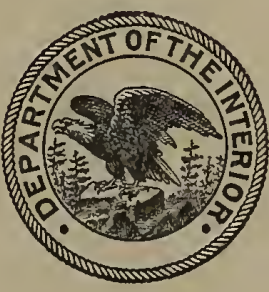

UNITED STATES

GOVERNMENT PRINTING OFFICE

WASHINGTON

1928 


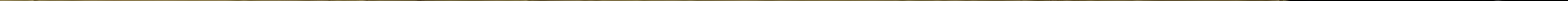

